FULL RESEARCH PAPER

\title{
Coyote Management Plans and Wildlife Watch: implications for community coaching approach to public outreach in south- ern California
}

\author{
ALEXANDER HEEREN ${ }^{*}$, HELEN BOWMAN ${ }^{1}$, VICTORIA MONROE ${ }^{1}$, DAVID \\ DODGE $^{2}$, AND KENT SMIRL ${ }^{2}$
}

${ }^{1}$ California Department of Fish and Wildlife, Wildlife Investigations Laboratory, 1701 Nimbus Rd, Rancho Cordova, CA 95670, USA

${ }^{2}$ California Department of Fish and Wildlife, Natural Resource Volunteer Program, 4665 Lampson Ave, Los Alamitos, CA 90720, USA

*Corresponding Author: alexander.heeren@wildlife.ca.gov

The majority of residents in southern California live in urban areas. Therefore, working with cities to promote tolerance and coexistence with urban wildlife is crucial to the conservation and management of native species. Human conflicts with coyotes (Canis latrans) illustrate the importance of incorporating the social sciences, particularly knowledge of human behavior, communication, and education, in a coyote management strategy. Here, we review 199 cities across southern California to determine which localities have a coyote management website or a coyote management plan. We also included cities that have collaborated with the California Department of Fish and Wildlife in developing a "Wildlife Watch" program model. Wildlife Watch (based on the Neighborhood Watch national crime prevention program) uses conservation-oriented principles to empower local communities, agencies, and residents to remove wildlife attractants and to exclude or deter coyotes from neighborhoods. We examine how cities with coyote management websites and programs differ from cities without, based on U.S. census demographics. Using data from coyote conflict and sighting tools (Coyote Cacher, iNaturalist, and CDFW's Wildlife Incident Reporting System) we compare coyote reports across cities with different management plans and websites. Finally, based on demographics from the US Census, we examine ways Wildlife Watch, or related programs, can be expanded and improved. An adaptive community-based program, like Wildlife Watch, offers a valuable toolkit to managers for navigating the diverse array of human perceptions, values, and attitudes regarding urban species and human-wildlife conflicts.

Key words: Canis latrans, co-existence, coyote, education, human-wildlife conflict, socioeconomic studies

Human-wildlife interactions leading to urban wildlife conflict, particularly involving coyotes (Canis latrans) is a major wildlife conservation and management issue in southern 
California (Baker and Timm 1998; Baker 2007). Human-wildlife conflict has a large social component (Madden and McQuinn 2020; Manfredo 2008). While the state manages wildlife through the California Department of Fish and Wildlife (CDFW), local governments and community leaders also have an important role to play in managing wildlife within their jurisdictions. As the majority of southern Californians oppose lethal control of coyotes [less than 30\% of Los Angeles, Orange, and San Diego residents are estimated to support lethal control of coyotes that injure or kill pets or domestic animals (Manfredo et al. 2018)] nonlethal methods to achieve co-existence and tolerance of wildlife is the primary goal for urban coyote management. In pursuit of coexistence, community outreach, education, and communication about how to avoid conflict are an important component of any coyote management plan (Baker 2007; Sponarski et al. 2016). Currently, CDFW works with local governments, non-governmental organizations (NGOs) and other partner agencies in developing community outreach and communication about wildlife.

An example of one such outreach program in California is Wildlife Watch (CDFW 2020). Wildlife Watch is a program model operated by CDFW that partners with cities, local communities, and neighborhoods. Wildlife Watch attempts to replicate the success of the crime prevention program, Neighborhood Watch (Bennett et al. 2008; National Neighborhood Watch 2020), by engaging and empowering residents to monitor and report coyote activity in their neighborhoods, remove food and attractants from their property, and safely deter habituated coyotes using hazing techniques. Using the concepts of Servant Leadership (Greenleaf 1977), Wildlife Watch volunteers and staff, known as Conservation Coaches, attend and present at townhall and community meetings, coordinate and conduct partner agency and community trainings. They serve as a conduit that conveys wildlife conservation management science and information from CDFW to local city and community leaders. One of the primary goals of Wildlife Watch Conservation Coaches is working with cities to develop an integrated wildlife management plan to address resident concerns about wildlife in a safe, sustainable, and socially acceptable manner. Wildlife management plans may be species specific, such as a regional, county or city coyote management plan, or more species inclusive and comprehensive in scope.

Cities face many other challenges in addition to managing urban wildlife. Understandably, many cities are unable to devote time and resources to developing a coyote management website, a coyote management plan, or participating in Wildlife Watch. Reviewing which cities currently have coyote management websites or plans can help identify which areas require additional help in developing a coyote management plan or outreach efforts.

\section{METHODS}

This review builds upon a previously developed data set (Heeren et al. 2020a). A total of 199 cities from six counties (Ventura, Los Angeles, Orange, Riverside, San Bernardino, and San Diego) were included in the review (Table 1). The U.S. Census (USCB 2020) was used to establish a list of incorporated cities and villages in southern California. Data from the US Census 2019 American Community Survey provided estimates for city demographics (population size, race and ethnicity, language fluency, and median income). The website for each city was examined for any links or references to coyote or wildlife issues. Using this approach, we identified the cities that had a coyote management website, or a coyote management plan, available to residents online. A list of cities that have collaborated with CDFW on a Wildlife Watch program was obtained from CDFW records. 
Table 1. Cities reviewed by county.

\begin{tabular}{lcccc}
\hline County & $\begin{array}{c}\text { Total } \\
\text { Cities } \\
\text { Reviewed }\end{array}$ & $\begin{array}{c}\text { Cities with } \\
\text { Website Only }\end{array}$ & $\begin{array}{c}\text { Cities with Coyote } \\
\text { Management Plans (Non- } \\
\text { Wildlife Watch Program) }\end{array}$ & $\begin{array}{c}\text { Cities with Wildlife } \\
\text { Watch Program }\end{array}$ \\
\hline Los Angeles & 87 & $32(37 \%)$ & $17(20 \%)$ & $9(10 \%)$ \\
Orange & 34 & $14(41 \%)$ & $8(24 \%)$ & $7(21 \%)$ \\
Riverside & 28 & $10(36 \%)$ & 0 & 0 \\
San Bernardino & 23 & $5(22 \%)$ & $1(4 \%)$ & 0 \\
San Diego & 18 & $2(11 \%)$ & 0 & 0 \\
Ventura & 9 & $3(33 \%)$ & 0 & 0 \\
\hline
\end{tabular}

Cities were considered to have a website about coyote management if they had any webpages, or information referencing, coyotes, on their city website. This information could be educational, or information on how to report coyote incidents. Cities were considered to have a management plan if they had a link on their website to a larger document (such as a PDF) about how the city manages coyotes. A coyote management plan is a requirement for Wildlife Watch, so all cities with a Wildlife Watch program had a website and management plan.

Reports about coyote activity were taken from a previous study of a state-wide analysis of the Coyote Cacher online reporting tool, the iNaturalist reporting tool, and CDFW's Wildlife Incident Reporting tool (Heeren et al. 2020b). For a more in-depth discussion of these tools, and how they differ, please see Heeren et al. 2020b. All three of these tools are publicly available and residents can use them to report coyote sightings as well as any human-coyote interactions.

The review, US Census data, and coyote reporting data were compared using Microsoft Excel Version 2010, ArcGIS.

\section{RESULTS}

Approximately one-third (33.2\%) of cities had a coyote management website, but no formal coyote management plan or document available to the public. Thirteen percent had a website with a coyote management plan. Eight percent of cities had a Wildlife Watch program. Of the 16 cities that had a Wildlife Watch program, 9 were in Los Angeles County and 7 were in Orange County.

Select demographics for the cities were compared using data from the US Census' 2019 American Community Survey (Table 2). These demographics were total population size, percentage of residents who identified their race or ethnicity as white or Caucasian, Asian, or Hispanic. Census estimates for the percentage of residents ( 5 years of age or older) that had difficulty speaking English were also included as well as the median household income. Language fluency and median income were only available for 133 cities in the review.

There was quite a range in the population size for the cities, regardless of whether the city had a coyote management website or plan (Table 2). Based on means and 95\% confidence intervals, cities with a website or plan had a higher percentage of residents identifying their race or ethnicity as Asian compared to cities without a website, plan, or Wildlife Watch program. Cities with a coyote management website or Wildlife Watch program had 
Table 2. Mean (95\% Confidence Interval) demographics of cities with coyote management website, plan, or program

\begin{tabular}{|c|c|c|c|c|c|c|}
\hline & $\begin{array}{c}\text { Population } \\
\mathrm{n}(1,000)\end{array}$ & $\begin{array}{l}\text { Identify Race } \\
\text { or Ethnicity } \\
\text { as White or } \\
\text { Caucasian }\end{array}$ & $\begin{array}{l}\text { Identify } \\
\text { Race or } \\
\text { Ethnicity } \\
\text { as Asian }\end{array}$ & $\begin{array}{l}\text { Identify } \\
\text { Race or } \\
\text { Ethnic- } \\
\text { ity as } \\
\text { Hispanic }\end{array}$ & Language & $\begin{array}{l}\text { Median } \\
\text { Income } \\
(\$ 1,000)\end{array}$ \\
\hline $\begin{array}{l}\text { No coyote man- } \\
\text { agement website } \\
\text { or plan found }\end{array}$ & $\begin{array}{c}72 \\
(42-103)\end{array}$ & $\begin{array}{c}69.4 \\
(65.9-72.9)\end{array}$ & $\begin{array}{c}10.1 \\
(8-12.2)\end{array}$ & $\begin{array}{c}48.3 \\
(43-53.6)\end{array}$ & $\begin{array}{c}20.4 \\
(18.2-22.6)\end{array}$ & $\begin{array}{c}67 \\
(62-71)\end{array}$ \\
\hline Website only & $\begin{array}{c}135 \\
(19-252)\end{array}$ & $\begin{array}{c}65.1 \\
(60.3-69.9)\end{array}$ & $\begin{array}{c}18.9 \\
(14.9-22.9)\end{array}$ & $\begin{array}{c}34.5 \\
(29.3-39.7)\end{array}$ & $\begin{array}{c}18.2 \\
(15.7-20.7)\end{array}$ & $\begin{array}{c}84 \\
(79-89)\end{array}$ \\
\hline $\begin{array}{l}\text { Coyote Manage- } \\
\text { ment Plan (Non- } \\
\text { Wildlife Watch) }\end{array}$ & $\begin{array}{c}81 \\
(42-121)\end{array}$ & $\begin{array}{c}57.5 \\
(49.3-65.7)\end{array}$ & $\begin{array}{c}23.3 \\
(16.2-30.4)\end{array}$ & $\begin{array}{c}39.4 \\
(30-48.8)\end{array}$ & $\begin{array}{c}26.5 \\
(22-31)\end{array}$ & $\begin{array}{c}73 \\
(65-81)\end{array}$ \\
\hline $\begin{array}{l}\text { Wildlife Watch } \\
\text { Program }\end{array}$ & $\begin{array}{c}109 \\
(62-156)\end{array}$ & $\begin{array}{c}64.2 \\
(56.7-71.7)\end{array}$ & $\begin{array}{c}23.4 \\
(17.2-29.6)\end{array}$ & $\begin{array}{c}28.5 \\
(18-39)\end{array}$ & $\begin{array}{c}15.6 \\
(12.1-19.1)\end{array}$ & $\begin{array}{c}94 \\
(84-104)\end{array}$ \\
\hline
\end{tabular}

a lower percentage of residents identifying their race or ethnicity as Hispanic than those with a Wildlife Watch program. Cities with a Wildlife Watch program had lower estimates of residents who had difficulty speaking English, and higher median incomes than cities without a Wildlife Watch program.

For reporting coyote activity, cities with a Wildlife Watch program, or coyote management plan, tended to have more reports (per 1,000 residents) than those without a Wildlife Watch program or without a coyote management plan (Table 3 ). However, due to the variance in reporting activity, the $95 \%$ confidence intervals are overlapping.

\section{DISCUSSION}

An adaptive community-based program, like Wildlife Watch, offers a valuable toolkit for managers to support safer human-wildlife interactions, increase awareness, and encourage coexistence and tolerance for urban wildlife, particularly coyotes. While a third of cities in southern California have some sort of website about coyote management, only a fifth have some sort of coyote management plan or Cities without a Wildlife Watch program tend to have a higher percentage of residents who identify their race or ethnicity as Asian and a

Table 3. Mean (95\% Confidence Intervals) coyote reports per 1,000 residents of cities with coyote management website, plan, or program

\begin{tabular}{llll}
\hline & Coyote Cacher & iNaturalist & CDFW WIR \\
\hline $\begin{array}{l}\text { No coyote management website or plan } \\
\text { found }\end{array}$ & $0.33(0.08-0.58)$ & $0.19(0-0.38)$ & $0.03(0.02-0.04)$ \\
$\begin{array}{l}\text { Website only } \\
\begin{array}{l}\text { Coyote Management Plan (Non-Wildlife } \\
\text { Watch) }\end{array}\end{array}$ & $0.97(0-1.79)$ & $0.29(0-0.76)$ & $0.04(0.03-0.05)$ \\
Wildlife Watch Program & $1.32(0.55-2.09)$ & $0.1(0.04-0.16)$ & $0.05(0.02-0.08)$ \\
\hline
\end{tabular}


lower percentage that identify has Hispanic than cities without a website or coyote management plan. Cities with a coyote management plan, or a Wildlife Watch program, also tend to have higher median incomes than cities without a coyote management website or plan.

This suggests that one way to improve Wildlife Watch, or related programs, is to figure out ways that cities can pool their resources to develop a program. Cities with a lower median income, and presumably a lower tax base, likely will have difficulties in devoting resources to wildlife management. By pooling resources, multiple cities in an area could develop a joint management plan or program. Such a collaborative management plan is currently underway with several of south Californian council of governments (COGs). Likewise, cities with limited financial resources may require assistance from CDFW or nongovernmental agencies, in applying for grants and other financial opportunities to develop a management plan or program.

While there did not seem to be a significant difference in language fluency between the cities with a plan or program to those without a plan or program, developing outreach materials in different languages could still promote a greater feeling of inclusivity with different communities. For example, most of the websites, plans, and Wildlife Watch program materials are in English. However, having Spanish-Language versions could help build connections to Hispanic communities.

It is difficult to make conclusions based on the results of the coyote reporting tools due to the great variance in reporting behavior (see Heeren et al. $2020 \mathrm{~b}$ for more discussion). However, it seems that cities with a management plan or Wildlife Watch program do have higher rates of reporting. This makes sense as monitoring and reporting coyote behavior is a major component of these plans and programs. Residents are encouraged to keep an eye out for coyotes and to report interactions in the interest of pinpointing specific neighborhoods or properties that may have a problem with coyote attractants. However, given the nature of this data, it is not possible to determine how much of an increase in reporting is due to having a coyote management plan or Wildlife Watch program. Cities that developed such plans and programs did so because they had a dedicated set of residents invested in coyote issues, and likely had higher rates of reporting coyotes prior to the development of the plans or programs.

Wildlife Watch is still in its infancy, and therefore, this review is largely a pilot study to establish a baseline set of data for future research. In light of this, the review has several important limitations. First of all, the review only examined city websites. Other organizations, such as counties, COGs, school districts, homeowner associations, wildlife rehabilitation centers, and NGOs are also important stakeholders in managing urban wildlife. Working with non-city organizations to build coexistence and tolerance for urban wildlife is crucial.

Secondly, the demographics used in this review are at the city level and not necessarily representative of those residents who participated in developing coyote management websites, plans, or Wildlife Watch. Regardless of the city-level demographics, it is important to make ensure inclusivity and transparency in developing any wildlife management plan or program. This will ensure that the decision-making process reflects a diversity of views as well as making the materials accessible to a diverse audience.

Despite being in its early stages, we believe Wildlife Watch serves as a valuable resource that cities can draw upon when managing conflict with coyotes. Through the principles of Conservation Coaching and Servant Leadership, Wildlife Watch engages and empowers communities to take responsibility for preventing human-wildlife conflict. To conclude with 
the words of a Wildlife Watch Conservation Coach in Orange County's City of Irvine: “My neighbors and I now feel empowered rather than helpless and have clear direction on how to cohesively move forward in a positive direction."

\section{LITERATURE CITED}

Baker, R. O. 2007. A review of successful urban coyote management programs implemented to prevent or reduce attacks on humans and pets in southern California. Wildlife Damage Management Conferences Proceedings 58:281-92.

Baker, R. O., and R. M. Timm. 1998. Management of conflicts between urban coyotes and humans in southern California. Pages 299-312 in R. O. Baker, and A. C. Crabb, editors. Proceedings of the 18th Vertebrate Pest Conference, University of California, Davis, CA, USA.

Bennett, T., K. Holloway, and D. Farrington. 2008. The effectiveness of neighborhood watch. Campbell Systematic Reviews 4(1):1-46.

California Department of Fish and Wildlife (CDFW). 2020. Wildlife Watch. Avaliable from: https://wildlife.ca.gov/wildlife-watch

Greenleaf, R. 1977. Servant Leadership: A Journey into the Nature of Legitimate Power and Greatness. Paulist Press, Mahwah, NJ, USA.

Heeren, A., V., Monroe, H., Bowman, D., Dodge, and K. Smirl. 2020. Watching out for human wildlife conflicts and vertebrate pests in southern California: the Wildlife Watch Program. Pages 305-307 in D. M. Woods, editor. Proceedings of the 29th Vertebrate Pest Conference. University of California, Davis, CA, USA.

Heeren, A., V., Monroe, and N., Quinn. 2020. The challenges, responsibility, and need to track human-coyote conflicts in California. Pages 238-242 in D. M. Woods, editor. Proceedings of the 29th Vertebrate Pest Conference. University of California, Davis, CA, USA.

Madden, F., and B. McQuinn. 2020. Conservation's blind spot: the case for conflict transformation in wildlife conservation. Biological Conservation 178:97-106.

Mandredo, M. J., L. Sullivan, A. W. Don Carlos, A. M. Dietsch, T. L. Teel, A. D. Bright, and J. Bruskotter. 2018. America's wildlife values: the social context of wildlife management in the U.S. National report for the research project entitled 'America's Wildlife Values.' Colorado State Universtiy, Fort Collins, CO, USA.

Manfredo, M. 2008. Who Cares About Wildlife?: Social Science Concepts for Exploring Human-Wildlife Relationships and Conservation Issues. Springer, Fort Collins, CO, USA.

National Neighborhood Watch. 2020. National Neighborhood Watch: Crime Prevention Through Neighborhood Cohesiveness and Collaboration. Available from https:// www.nnw.org

Sponarski, C., J., Vaske, A., Bath, and T. Loeffler. 2016. Changing attitudes and emotions toward coyotes with experiential education. Journal of Environmental Education 47(4): 296-306.

Submitted 15 December 2020

Accepted 21 January 2021

Associate Editor was A. Baker 